\title{
Diagnostic Accuracy of Frozen Section in Various Thyroid Disorders as Compared with Paraffin Section from the Same Cases
}

\author{
Kuntjoro, Benyamin Makes
}

\begin{abstract}
Abstrak
Penelitian ini adalah penelitian retrospektif yang menggunakan data dari Sub Unit Patologi Anatomi, Instalasi Bedah Sentral, RS Dr. Cipto Mangunkusumo, mulai Januari 1990 sampai Desember 1991. Selama dua tahun dilakukan 207 kasus potong beku jaringan tiroid. Dari 185 kasus yang diteliti,ditemukan 157 kasus (84,9\%) kelainan jinak dan 28 kasus (15,1\%) ganas. Pada sediaan parafin ditemukan 158 kasus $(85,4 \%)$ jinak dan $27(14,8 \%)$ ganas. Terdapat positif palsu 3 kasus dan negatif palsu 2 kasus. Sensitivitas mencapai $92,6 \%$, spesifisitas $98,1 \%$, ketepatan keseluruhan $97,3 \%$, nilai ramalan positif $89,3 \%$ dan nilai ramalan negatif $98,7 \%$. Dengan analisis tersebut disimpulkan bahwa ketepatan diagnosis potong beku jaringan tiroid cukup tinggi, sehingga cara ini masih diperlukan dalam menentukan keganasan tiroid dengan cepat.
\end{abstract}

\begin{abstract}
This is a retrospective study using the data from the Anatomic Pathology Sub Unit of the Central Surgery Instalation of the Dr. Cipto Mangunkusumo Hospital, from Januari 1990 to December 1991. During a two-year period there were 207 cases of thyroid frozen sections. A number of 185 cases have been reviewed, 157 (84.9\%) were benign and 28 (15.1\%) were malignant. In paraffin sections 158 cases $(85.4 \%)$ were benign and 27 cases (14.6\%) were malignant. There were 3 false positive and 2 false negative cases. The sensitivity was $92.6 \%$, specificity $98.1 \%$ and the accuracy $97.3 \%$. The positive predictive value was $89.3 \%$ and the negative predictive value $98.7 \%$. From the analysis we conclude that there is high accuracy in frozen section diagnosis of the thyroid nodules. This method is still necessary to decide rapidly any thyroid malignancy.
\end{abstract}

Keywords: accuracy, thyroid frozen section.

\section{INTRODUCTION}

The major reason for performing frozen section is to obtain a diagnosis of a pathologic process, chiefly to determine quickly whether it is malignant or benign. Another reason is to determine the presence or absence of tumor metastasis in lymph nodes. Frozen section is also done for tissue identification and for determination of the adequacy of resection margins of a malignant lesion. In other words, frozen section will help the surgeon to determine the treatment. Since diagnosis is made by the pathologist, the result of the frozen section will have serious consequences in the treatment of the patient. So, the accuracy of this method has to be evaluated.

In general, frozen section has a high degree of accuracy. ${ }^{1-5}$ For thyroid tissue, the accuracy is claimed to be about $87 \%$ to nearly $98 \% .^{6-10}$ We hope that a surgeon can determine and take the right tissue samples. No pathologist can overcome the handicap of choosing the inaccurate tissue. Consequently, both the surgeon and the pathologist need to understand each other to give maximum services. ${ }^{1,6,11}$ The use of this technique is limited and the evaluation is more difficult than the paraffin slides. Especially for thyroid frozen section, prerequisites are needed in order to get a high accuracy diagnosis. The most common difficulty in frozen section is in determining the malignancy on follicular lesions. We ussually get difficulties in diagnosing the nodule. So, if we find a follicular lesion and we don't find vascular or capsular invasion, we must delay the diagnosis, till the paraffin slide in process is ready to use.

The aim of this retrospective study is to know the accuracy of frozen section diagnosis in some thyroid-

Department of Anatomic Pathology, Faculty of Medicine University of Indonesia/Cipto Mangunkusumo Hospital, Jakarta, Indonesia. 
disorders compared with paraffin section from the same cases.

\section{MATERIALS AND METHODS}

The material was obtained from the Anatomic Pathology Sub Unit of the Central Surgery Instalation of the Cipto Mangunkusumo Hospital from January 1990 to Desember 1991. All their clinical data and paraffin sections were examined. We found a number of 207 cases of thyroid frozen sections within the period and 185 of which were included in this research. The remainder were not included in this research because the slides were lost ( 4 cases) and the rest were cases with follicular lesions (18 cases).

\section{Efficacy}

To evaluate the accuracy of frozen section diagnosis we need to know the efficacy of this method. Therefore we made binomial random numbers to simulate the 2 $\mathrm{x} 2$ table as shown in Fig 1. Efficacy is the proporsion of malignancy coinciding with paraffin diagnosis as a gold standard. Comparison between this method and the gold standard produces 4 possibilities, those are: true positive (a), false positive (b), true negative d) and false negative (c).

\begin{tabular}{|c|c|c|}
\hline$a$ & $b$ & $a+b$ \\
\hline$c$ & $d$ & $c+d$ \\
\hline$a+c$ & $b+d$ & $a+b+c+d$ \\
\hline
\end{tabular}

Fig 1. The $2 \times 2$ table

\section{Sensitivity}

Sensitivity is the probability that the malignant tumor can be diagnosed on the patients proved to bear a malignant tumor.

$$
\text { Sensitivity }=\frac{\text { true positive }}{\text { true positive }+ \text { false negative }}
$$

\section{Specificity}

Specificity is the probability that a benign lesion can be diagnosed on patients having no malignant tumor.

$$
\text { Specificity }=\frac{\text { true negative }}{\text { true negative }+ \text { false positive }}
$$

\section{Accuracy}

Accuracy is the combination of sensitivity and specificity.

$$
\text { Accuracy }=\frac{\text { true positive }+ \text { true negative }}{\text { true pos. }+ \text { false pos. }+ \text { true neg. }+ \text { false neg. }}
$$

\section{Positive and negative predictive value}

Positive predictive value of a test is the probability that a patient has a malignant tumor if the test is positive for malignant tumor.

$$
\text { Positive predictive value }=\frac{\text { true positive }}{\text { true positive }+ \text { false positive }}
$$

Negative predictive value of a test is the probability that a patient has no malignant tumor if the test is negative.

$$
\text { Negative predictive value }=\frac{\text { true negative }}{\text { true negative }+ \text { false negative }}
$$

\section{RESULTS}

From the 185 cases studied we found $157(84.9 \%)$ and $28(15.1 \%)$ cases with benign and malignant lesions respectively, at frozen section. Benign lesions cover adenomatous goiter, Basedow's disease, chronic thyroiditis and thyroglossal cyst (see Table 1), while malignant lesions consist of papillary carcinoma, follicular carcinoma, anaplastic carcinoma and unidentified carcinoma (see Table 2).

Table 1. Benign lesions at frozen section

\begin{tabular}{lrr}
\hline Type of lesion & $\begin{array}{c}\text { number } \\
\text { of cases }\end{array}$ & $\%$ \\
\hline Adenomatous goiter & 153 & 97.5 \\
Basedow's disease & 2 & 1.3 \\
Chronic thyroiditis & 1 & 0.6 \\
Thyroglossal cyst & 1 & 0.6 \\
\hline Total & 157 & 100 \\
\hline
\end{tabular}


Table 2. Malignant lesions at frozen section

\begin{tabular}{lrc}
\hline Type of lesion & $\begin{array}{c}\text { number } \\
\text { of cases }\end{array}$ & $\%$ \\
\hline Papillary carcinoma & 16 & 57.1 \\
Follicular carcinoma & 5 & 17.9 \\
Anaplastic carcinoma & 3 & 10.7 \\
Carcinoma & 4 & 14.3 \\
\hline Total & 28 & 100 \\
\hline
\end{tabular}

From paraffin sections there were 158 benign and 27 malignant lesion cases. Benign lesions cover adenomatous goiter, follicular adenoma, Hurthle cell adenoma, Basedow's disease, chronic thyroiditis and thyroglossal cyst (Table 3). Malignant lesions cover papillary carcinoma, follicular carcinoma, anaplastic carcinoma, Hurthle cell carcinoma and squamous cell carcinoma (see Table 4).

Table 3. Benign lesions at paraffin section

\begin{tabular}{lrr}
\hline Type of lesion & $\begin{array}{c}\text { number } \\
\text { of cases }\end{array}$ & $\%$ \\
\hline Adenomatous goiter & 150 & 94.9 \\
Follicular adenoma & 2 & 1.3 \\
Hurthle cell adenoma & 2 & 1.3 \\
Basedow's disease & 2 & 1.3 \\
Chronic thyroiditis & 1 & 0.6 \\
Thyroglossal cyst & 1 & 0.6 \\
\hline Total & 158 & 100 \\
\hline
\end{tabular}

Table 4. Malignant lesions at paraffin section

\begin{tabular}{lcc}
\hline Type of lesion & $\begin{array}{c}\text { number } \\
\text { of cases }\end{array}$ & $\%$ \\
\hline Papillary carcinoma & 19 & 70.4 \\
Follicular carcinoma & 5 & 18.5 \\
Anaplastic carcinoma & 1 & 3.7 \\
Hurthle cell carcinoma & 1 & 3.7 \\
Squamous cell carcinoma & 1 & 3.7 \\
\hline Total & 27 & 100 \\
\hline
\end{tabular}

Table 5. Diagnostic errors

\begin{tabular}{|c|c|c|c|}
\hline Frozen section & & $\begin{array}{c}\text { Paraffin } \\
\text { (Gold Standard) }\end{array}$ & \\
\hline Papillary carcinoma & $1 "$ & adenomatous goiter & 1 \\
\hline Carcinoma & $2^{*}$ & adenomatous goiter & 1 \\
\hline & & Hurthle cell adenoma & 1 \\
\hline Adenomatous goiter & $2^{\star \star \star}$ & Papillary carcinoma & 2 \\
\hline
\end{tabular}

From the above data we found three false positive and two false negative cases (see Table 5). After being analysed we found that the sensitivity was $92.6 \%$, specificity $98.1 \%$, accuracy $97.3 \%$, positive predictive value $89.3 \%$ and negative predictive value $98.7 \%$.

\section{DISCUSSION}

Thyroid frozen section needs choosing the sample in detail, both by surgeon and pathologist. The wrong sample makes false negative.

Macroscopic examination is necessary. At macroscopic examination we are usually able to make an estimation of the diagnosis. For the exact diagnosis, we need histopathological examination. To increase the accuracy of frozen section needs other examinations, for example, fine needle aspiration and imprint cytology. Aspiration and imprint cytology's cells can be observed clearly by both cytologic examinations. It is said that imprint cytology can help to increase the accuracy of frozen section diagnosis. $2,12,13.14,15$

In this observation we get $97.3 \%$ of accuracy. There are some different results from other observations, ranging from 87 to nearly $98 \%$.

The most common benign lesion is adenomatous goiter. The histological picture of this lesion varies. There are large and small follicles. The large follicles are lined by flat epithelium and the lumen filled with colloid. The small follicles are lined by thoracal/cuboidal epithelial cells, the lumen is empty or filled with a small amount of colloid. Usually there are fibrosis, haemorrhages and calcifications. Sometimes it is encapsulated and difficult to differentiate from follicular adenoma. ${ }^{6,16,17}$

The most common thyroid malignancy is papillary carcinoma. This lesion is marked by the presence of papillary growth, psammoma bodies and nuclear changes. The nuclear chromatin groups at the periphery of the nucleus and has a ground glass appearance or Orphan Annie nuclei. ${ }^{6,16,18,19}$ Whereas at 
cytology, we can see intranuclear cytoplasmic invaginations in papillary carcinoma. ${ }^{6,16,18,20}$ Not all papillary growth is malignant. There are some differences between papillary carcinoma and papillary hyperplasia. In papillary hyperplasia the cells are arranged as one layer and the round nuclei lay at the basal or at the middle of the cells. The chromatin is delicate and homogenous. ${ }^{6,16}$

In this study, follicular carcinoma is diagnosed by frozen section in 5 cases $(17,9 \%)$. The malignancy of this tumor is marked by the existence of vascular and capsular invasion. ${ }^{11,16,17,21}$ Follicular carcinoma is devided into two types, those are minimally and widely invasive. For pathologist, the main difficulty is in distinguishing minimally invasive follicular carcinoma from follicular adenoma for the two lesions have the same appearance both in histological $11,16,17,19$ and cytological picture. ${ }^{6,15,17}$ The malignancy is determined by the existence of capsular and vascular invasion. If the capsular and vascular invasion can not be found, the diagnosis must be delayed until paraffin slides are prepared and this lesion is grouped into follicular lesion. ${ }^{6}$

From paraffin section, these follicular lesions consist of adenomatous goitre, follicular adenoma, follicular carcinoma and follicular variant of papillary carcinoma. ${ }^{6}$

In widely invasive thyroid carcinoma, the tumor cells have invaded the blood vessels or spread out of the capsul so that, there is no problem in making the diagnosis.

In this study there were 3 cases $(10,7 \%)$ of anaplastic carcinoma diagnosed by frozen section. The diagnosis of this type of malignancy is based on the existence of cell anaplasia, without folicle formation and the existence of necrosis. The tumor cells vary in diametres. They can be small with round nuclei and look like malignant lymphoma cells, spindle shaped and look like fibroblast or large and multi-nucleated (giant cells). ${ }^{6,11,16,19}$

This tumor can be differentiated from medullary thyroid carcinoma, because the latter produces some polypeptides and factors, e.g.: calcitonin, carcinoembryonic antigen, ACTH, serotonin, enolase etc. $22-25$

\section{CONCLUSION}

As a conclusion, the frozen section diagnosis of the thyroid disorders in Dr. Cipto Mangunkusumo Hospital has a high accuracy and the level of accuracy is the same as the paraffin section diagnosis. Thus, frozen section of the thyroid is still necessary to support surgeon in making diagnosis quickly.

\section{REFERENCES}

1. Kaufman Z, Lew S, Griffel B, Dinbar A. Frozen section diagnosis in surgical pathology. A prospective analysis of 526 frozen sections. Cancer 1986;57:377-9.

2. Oneson RH, Minke JA, Silverberg SG. Intraoperative pathologic consultation. An audit of 1.000 recent consecutive cases. Am J Surg Pathol 1989;13:237-43.

3. Sawady J, Berner JJ, Siegler EE. Accuracy of and reasons for frozen sections: a corelative, retrospective study. Human pathology 1988;19:1019-23.

4. Tjahjadi G, Soutrisno E. Peranan pemeriksaan potong beku pada diagnosis keganasan. Muktamar Nasional ke-II Perhimpunan Ahli Bedah Tumor Indonesia. Jakarta, 7-9 April 1983.

5. Taufik E, Mangunkusumo R. Peran potong beku pada penanganan tumor ovarium. In:Kumpulan naskah lengkap Kongres Nasional ke X IAPI. Surabaya, 5-8 Juli 1990.

6. Kraemer BB. Thyroid.In:Silva EG, Kraemer BB (editors) Intraoperative pathologic diagnosis frozen section and other techniques. Sydney: William \& Walkins, 1987:51-69.

7. Shaha A, Gleich L, Di Maio T, Jaffe BM. Accuracy and pitfalls of frozen section during thyroid surgery. J Surg Oncol 1990; 44:84-92.

8. Irish JC, van Nostrand AWP, Asa SL, Gullane P, Rotstein L. Accuracy of pathologic diagnosis in thyroid lesions. Arch Otolaryngol Head Neck Surg 1992;118:918-22.

9. Rosen Y, Rosenblatt P, Saltzman E. Intraoperative pathologic diagnosis of the thyroid neoplasms. Report on experience with 504 specimens. Cancer 1990;66:2001-6.

10. Kingston GW, Bugis SP, Davis N. Role of frozen section and clinical parameters in distinguishing benign from malignant folicular neoplasms of the thyroid. Am J Surg 1992; 164: 603-5.

11. Mendelsohn G. Pathology of the thyroid disease. In: Diagnosis and pathology of the endocrine disease. Philadelphia: Lippincott, 1988:37-117.

12. Pluot M, Faroux MJ, Patey M, Mallaisy T, Simatos A. Contributions of imprint cytology to the diagnosis of tumors of the thyroid. Arch Anat Cytol Path 1989; 37:36-9.

13. Abrahams $\mathrm{C}$. The scrimp tecnique-a methode for the rapid diagnosis of surgical pathology specimens. Histopathology 1979;2:255-66.

14. Kontozoglou TE, Cramer HM. The advantages of intraoperative cytology. Analysis of 215 smears and review of the literature. Acta cytologica 1991;35:154-64.

15. Mair S, Lash RH, Suskin D, Mendelshon G. Intraoperative surgical specimen evaluation: frozen section analysis, cytologic examination, or both? A comparative study of 206 cases. Am J Clin Pathol 1991; 96:8-14.

16. Lloyd RV. Thyroid. In:Endocrine pathology. New York: Springer-Verlag, 1990:37-69.

17. LiVolsi VA. Follicular lesions of the thyroid. In: Surgical pathology of the thyroid. Philadelphia: WB Saunders, 1990: 173-212.

18. Kini SR. Papillary carcinoma. In: Thyroid. Guides to clinical aspiration biopsy. New York-Tokyo:Igaku-Shoin, 1987: 121-87 
19. Hedinger C, Williams ED, Sobin LH. Histological typing of tumours. 2nd ed. Berlin: Springer-Verlag, 1988.

20. Orell SR, Sterrett GF, Walters MNI, Whitaker D. The thyroid gland. In: Manual and atlas of fine needle aspiration cytology. Edinburgh: Churchill Livingstone, 1986:65-86.

21. Rosai J, Carcangiu ML, De Lellis RA. Tumors of the thyroid gland. Atlas of tumor pathology. 3rd ser. Washington DC:AFIP, 1990:49-63.

22. Lloyd RV, Sisson JC, Marangos PJ. Calcitonin, carcinoembryonic antigen and neuron-specific enolase in medullary thyroid carcnoma. An immunohistochemical study. Cancer 1983;51:2234-9.
23. Birkenhager JC, Upton GV, Seldentarh HJ, Krieger DT, Tashjian $\mathrm{J}_{r}$ AH. Medullary thyroid carcinoma:ectopic production of peptides with ACTH-like, corticotrophin releasing factorlike and prolactin production-stimulating activities. Acta Endocrinol 1976;83:280-92.

24. Deflos LJ, Bone III HG, Parthemore JG. Immunohistological studies of medullary thyroid carcinoma and $C$ cell hyperplasia. J Clin Endocrinol Metab 1980;51:857-62.

25. Beerman H, Rigaud C, Bogomoletz WV, Hollander H, Veldhuizen RW. Melanin production in black medullary thyroid carcinoma (MCT). Histopathology 1990;16:227-33. 